\title{
Hand hygiene compliance in India
}

\author{
D Sureshkumar ${ }^{*}$, V Ramasubramanain, K Abdulghafur, V Nagvekar \\ From International Conference on Prevention \& Infection Control (ICPIC 2011) \\ Geneva, Switzerland. 29 June - 2 July 2011
}

\section{Introduction / objectives}

Healthcare workers (HCWs) hands are the most common vehicle for the transmission of healthcare-associated pathogens. Evidence-based guidelines for healthcare workers' hand hygiene practices exist, but compliance with these is internationally low. Monitoring hand hygiene compliance and providing healthcare workers with feedback regarding their performance are considered integral parts of a successful hand hygiene promotion program. But in India very few studies addressed the issue of hand hygiene compliance. The main aim of the study was to assess the hand hygiene compliance among different health care workers.

\section{Methods}

This was a cross sectional study. The infection control professionals randomly observed the compliance of hand hygiene practices of different health care workers during their routine patient care in different wards. The HCWs were unaware that they were being observed.

\section{Results}

In the present study 340 hand hygiene activates were observed. Alcohol based hand rub (69\%) was the principle mode of hand hygiene among HCWs. Nurses (37\%) \& Doctors $(28 \%)$ were the main participants compared to other ancillary staffs. Hand hygiene compliance before and after patient/environment contact among doctors, nurses and ancillary staffs were $66 \%, 62 \%$ and $54 \%$ respectively. Doctors, nurses and ancillary staffs were followed hand hygiene steps orderly in $69 \%, 56 \%$ and $51 \%$ of the times.

\section{Conclusion}

Hand hygiene compliance rate among doctors and nurse were high compared to ancillary staffs. Doctors followed Hand hygiene steps orderly on most of the occasions.

Infectious disease, Apollo Hospitals, Chennai, India
Ancillary staffs need to be educated about hand hygiene to improve their compliance.

\section{Disclosure of interest}

None declared.

Published: 29 June 2011

doi:10.1186/1753-6561-5-S6-P259

Cite this article as: Sureshkumar et al.: Hand hygiene compliance in India. BMC Proceedings 2011 5(Suppl 6):P259.
Submit your next manuscript to BioMed Central and take full advantage of:

- Convenient online submission

- Thorough peer review

- No space constraints or color figure charges

- Immediate publication on acceptance

- Inclusion in PubMed, CAS, Scopus and Google Scholar

- Research which is freely available for redistribution
() Biomed Central

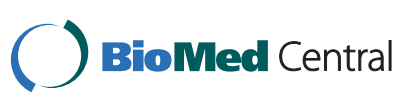

C 2011 Sureshkumar et al; licensee BioMed Central Ltd. This is an open access article distributed under the terms of the Creative Commons Attribution License (http://creativecommons.org/licenses/by/2.0), which permits unrestricted use, distribution, and reproduction in any medium, provided the original work is properly cited. 